\title{
Prof. Dr. Bánóczy Jolán emlékére
}

\section{(1929-2016)}

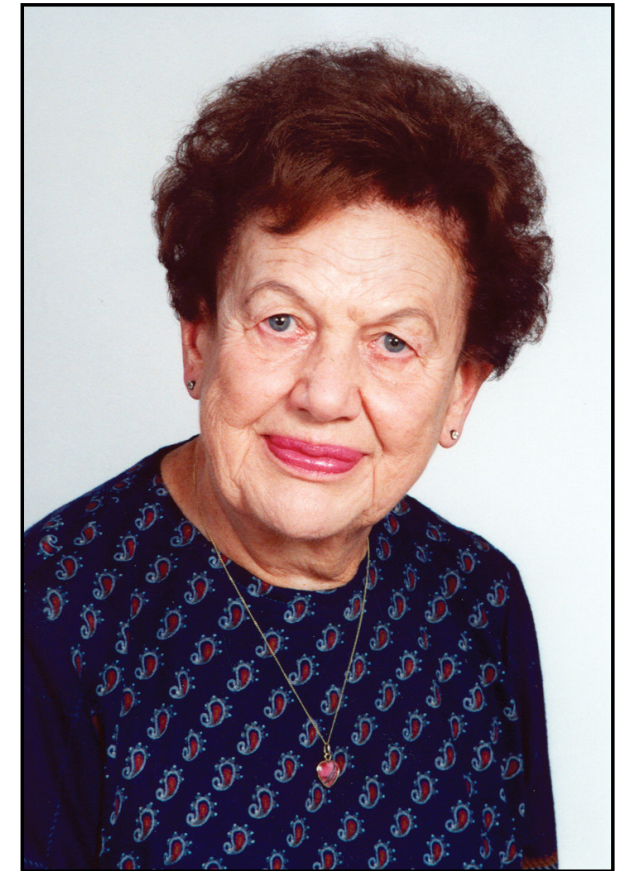

Nagyon nehéz megemlékezést írni, amikor egy közösségboól elmegy valaki, különösen olyan személy, mint Bánóczy Professzor Asszony, a magyar fogtudomány XX. századának ikonikus alakja, aki nemcsak a hazai és nemzetközi tudományos lábnyomát hagyta itt, hanem aki személyesen is iskolapélda lehetett többünknek. Öszszekötője a múltnak a jelenhez, s tanítványai révén a jövő meghatározója is egyben, a magyar fogorvosképzés emblematikus nagy alakja.

Hivatalos és tudományos megemlékezések bizonyára készülnek, amelyek pontosan ismertetik munkásságát. Ám emberi oldalát szeretném méltatni, kicsit jobban megmutatva személyiségét.

Közeli ismerősei, kollégái, kiemelt tanítványai, barátai csak egyszerúen Jolikának hívták. Ebben benne volt a közelség, az elismerés, az ő kiterjedő, óvó, gondoskodó anyai szeretete is, de a nói tudósok kezdeti helykeresése is a társadalom mentalitásában (egy férfi professzort sose neveznének Jánoskának, Lacikának vagy Gyurikának). Ám ő volt olyan kemény és határozott, letett több hazai és nemzetközi „embernyi” tudományos munkát, kutatást a tudomány asztalára, hogy a magyar szokásos társadalmi kommunikációs kultúra ellenére kivívta a maximális tiszteletet és a megbecsülést a Jolikázás ellenére.
Ahogy a róla készült Titoknyitogató könyvben elmondta: „...én egy egészen másfajta világban nöttem fel, mint a mai.” Másfajta, mert szigorú neveltetése eredményeképpen olyan személyiséggé vált, akinek jelleme példakép lett a kitartás, szorgalom, pontosság, racionalitás, a jólneveltség, figyelem és fegyelem együttlétezésével. Az Angolkisasszonyok - nói szerzetesrend, apostoli hivatással - rendszerében igen szigorúan nevelkedett. Mindezeket a tulajdonságait az apácák megmásíthatatlan következetességgel kérték számon a növendékeiktől, s ezzel automatizmusukká vált. Nála sosem fordulhatott elő a késés, mindig pár perccel előbb érkezett meg a megbeszélt, megállapodott időben. Semmit nem bízott a véletlenre. Tudatosan, átgondoltan, felkészülten, előkészítve érkezett bármilyen megbeszélésre. Külleme: haja, ruhája, arca és belsốje mindig összerendezett és visszafogott volt. Sugárzott belőle a belső és külső rend összhangja, harmóniája. Hihetetlen teherbírása is ott alakult ki. Ugyanakkor, amikor csak lehetett, vidám és mosolygós volt, remek öniróniával, humorral. Szépen és szabatosan fogalmazott, mindig a legpontosabb kifejezéseket találta meg az adott témához. Remek előadó volt. Ugyanilyen szépen beszélt magas szinten, igényesen három idegen nyelven, amelyeket még gyerekkorában sajátított el. A franciát egy Sorbonne-on végzett tanártól tanulta, a németet és az angolt már kora gyerekkorában a családban megismerte: németül a nagymamájától, angolul a mamájától tanult meg beszélni, ugyanis ő amerikai állampolgár volt, remek angoltudással. Késóbb kiváló tanárok segítségével tökéletesítette a nyelvtudását, ami felbecsülhetetlen előnyt jelentett a hatvanas-hetvenes években, amikor szinte senki nem beszélt a kötelező oroszon kívül más nyelven. Így a nemzetközi szakmai társaságokban és konferenciákon, szakmai együttmúködésben szinte egyedül állt a nyelvtudásával. A magas szintû́ szakmai tudásán kívül ezért is alakulhatott ki körülötte az a hatalmas nemzetközi tudományos hálózat, amelyben méltó elismeréseket szerzett.

Mindig szorgalmas és érdeklődő diák volt. Komolyan vette a felkészülést az orvosi hivatásra. Apja a MABI (Magántisztviselők Biztosító Intézetének) fogorvosa volt. Egyetemi évei után Balogh Károly professzor meghívására az akkor induló Fogorvosi Kar klinikájára került, konkrétan Szokolóczy-Syllaba Bélához (a vezetéses érzéstelenítés technikájának kidolgozója) az ambulanciára, s mint sokan a kezdetekkor, a foghúzás elsajátításával 
kezdte fogorvosi pályáját. Később Sugár tanár úr vezetésével az úgynevezett szájbetegosztályon a leukoplakiával kezdett el foglalkozni. Ö lett ennek a szájüregi praecancerosus állapotnak a szakértője. Egyetemi éveim alatt én is hozzá vittem el közeli rokonomat, akkor gyakorlatvezetőm volt e tárgyból. Személyesen nemcsak a tanár oldaláról, hanem a hozzátartozói oldaláról is megismerhettem gondos, körültekintő orvosi munkáját, odafigyelését és törődését, elismert tudása mellett.

Tudománytisztelete és igényessége igen magas szintre emelte a magyar és nemzetközi fogtudományt. Keveset tudnak nemzetközi sikereiről, de bárhol is fordult meg a világban, otthagyta tudományos lábnyomát Japántól Amerikáig, Angliától Dél-Amerikáig, mindenhol elismert, elfogadott szakembernek tartották. Hatalmas nemzetközi szakmai „családot” tartott össze.

Kedves volt és minden részletre kitekintő, gondoskodó, utódokat nevelő, iskolateremtő tanár. Nem tû́rte a linkséget, a pontatlanságot, a tudatlanságot, igényessége az élet minden területén meghatározó volt.

Nagy gonddal ápolta a fogtudományi hagyományokat, személyeket, megbecsülte a múltat, így könnyen építhette a jövőt. A Fogorvosi Kar 50 éves évfordulóját Ó szervezte meg mint alapító szemtanú és a múlt nagy tisztelője. Összefogott, remek, racionális, rövid, de célratörő értekezleteket tartott. Mindent megoldott és elintézett. Azonnal cselekedett, gyors volt és hatékony.

Egyedülálló volt abban is, hogy első női dékánként mutatta meg remek szervezőképességét az akkor már új elnevezésű Semmelweis Egyetemen. Egyből mindent át- látott, igen határozottan és mindig jól döntött. Munkatársaival lojális volt, érzékeny a személyes problémákra. Fejben tartott mindent, és szinte sosem tévedett. Bármit ígért, azt betartotta.

A Magyar Tudományos Akadémia doktora volt, hoszszú évekig szinte egyedüli képviselője az ilyen minősítésnek.

Nemesen és bátran vezette a Fogtudományi Kart, pont úgy, mint ahogy viselte ismert és tudott betegségét.

Életemben meghatározó személyiség volt. Egyetemi éveim után a tudományos életben voltak közös munkáink. Minden megbeszélésen volt lényeges és érdemleges mondandója, irányt adó véleménye. Kiváló szaklektora volt néhány könyvemnek. Az akadémiai doktori védésem egyik opponense volt, lábtörése ellenére. Hozzáértő, lényegre törő véleménye és kérdései segítették munkámat, pedig akkor többedik sikertelen mútétje után lábadozott. Kedélye és tartása töretlen volt. Mindig meghatározó példaképem a kitartás, az eró és az önfegyelem irányításában. Pótanyám volt, és én egyike a kiemelt "lyányainak”. Több tanítványát fogadta fiának vagy "lyányának". Kísérte utunkat, figyelt ránk akkor is, ha esetleg kikerültünk a látószögéból.

Különleges egyéniség volt. Olyan igaz ember, a kevesekből.

Jolikám, nyugodj békében!

Forrai Judit e-mail: forrai.judit@med.semmelweis-univ 